Sains Malaysiana 50(1)(2021): 201-206

http://dx.doi.org/10.17576/jsm-2021-5001-20

\title{
Startle Habituation: A Tool for Assessing Information Processing Deficits in Zebrafish Model of Schizophrenia
}

(Kejutan Habituasi: Suatu Alat untuk Menilai Maklumat Defisit Pemprosesan pada Model Ikan Zebra Skizofrenia)

Wen-Yang Png, PeK-Yee Tang, Satoshi Ogawa, Ishwar Parhar, Siew-Ying MoK*

\begin{abstract}
Prepulse inhibition (PPI) and habituation of acoustic startle reflex have been extensively used to assess deficits in the sensorimotor functions of human patients and animal models of schizophrenia. These assays require expensive and sophisticated experimental setup for fine control of acoustic stimuli and sound attenuation. In this study, we investigate whether startle habituation assay based on mechanical (tap) stimuli can induce similar impairment in the habituation response in the schizophrenia model of larval zebrafish. For this purpose, a custom startle apparatus consisting of a 9 V push and pull solenoid and an Arduino Uno microcontroller was used to generate tap stimuli at desired intervals. Our results showed that tap stimuli at $1 \mathrm{~Hz}$ effectively evoked startle response in the control fishes which habituated after a few trials. The habituation response was significantly impaired in the MK801-induced schizophrenia model, similar to that elicited by acoustic startle stimuli in a previous study. We propose this simple and inexpensive method as an alternative tool for studying information processing and attention deficits in the pharmacological model of schizophrenia in zebrafish.
\end{abstract}

Keywords: Habituation; schizophrenia; startle; tap stimuli; zebrafish

ABSTRAK

Inhibisi prepulse dan habituasi refleks kejutan akustik telah digunakan secara meluas untuk menilai defisit dalam fungsi sensorimotor pesakit dan model haiwan skizofrenia. Ujian sebelum ini memerlukan peralatan uji kaji yang mahal dan canggih untuk kawalan halus rangsangan akustik dan pelemahan bunyi. Dalam kajian ini, kami mengkaji sama ada ujian habituasi berdasarkan rangsangan mekanikal (ketukan) boleh menyebabkan kemerosotan yang sama dalam tindak balas seperti yang ditunjukkan dalam model habituasi skizofrenia ikan zebra. Untuk tujuan ini, kami membina radas yang terdiri daripada solenoid tolak-dan-tarik dan mikropengawal Arduino Uno untuk menjana rangsangan mekanikal mengikut selangan yang dikehendaki. Hasil kajian kami menunjukkan bahawa rangsangan ketukan pada $1 \mathrm{~Hz}$ berkesan menimbulkan tindak balas kejutan kepada ikan kelompok kawalan dan menunjukkan habituasi selepas beberapa set rangsangan mekanikal. Tindak balas habituasi dalam model skizofrenia yang diinduksikan oleh MK801 terjejas dengan ketara, sama seperti yang ditunjukkan dalam kajian rangsangan akustik sebelum ini. Kami mencadangkan kaedah yang mudah dan berpatutan ini sebagai alternatif untuk mengkaji pemprosesan maklumat dan defisit perhatian dalam model farmakologi skizofrenia ikan zebra.

Kata kunci: Habituasi; ikan zebra; kejutan; rangsangan mekanikal; skizofrenia

\section{INTRODUCTION}

Startle reflex is a universal sensorimotor response that is rapidly produced after the initiation of a sudden or strong stimulus (Abel et al. 1998; Geyer et al. 1990). This primitive reflex displays several forms of plasticity such as prepulse inhibition (PPI) and habituation which are important that they allow the nervous system to filter out irrelevant stimuli (Basnet et al. 2019). Since the past few decades, plasticity of startle reflex has been the focus of interest in a multitude of psychiatric and neurological diseases where the functions of sensorimotor pathways are thought to be impaired, such as schizophrenia (Bolino et al. 1994, 1992; Geyer \& Braff 1982; Parwani et al. 2000). The sensitivity of PPI and habituation to pharmacological manipulations 
(Geyer et al. 1990; Swerdlow et al. 1992) also rendered them an invaluable tool for probing sensorimotor function deficits in the animal models of these disorders.

Zebrafish has emerged as a popular animal model system for studying schizophrenia in recent years due to the several experimental advantages that it possesses (Gawel et al. 2019; Norton 2013). Various methods have been used to create schizophrenia model of zebrafish, including knockdown technique (Wood et al. 2009) and induction using NMDA receptor antagonists such as dizocilpine (MK801), ketamine, and phencyclidine (Chen et al. 2010; Wang et al. 2019). As in human research, studies of PPI and habituation in schizophrenia model of zebrafish were based upon a common mode of startle stimulus, which is acoustic startle. These studies require dedicated startle apparatus for generating acoustic stimuli of varying intensities and frequencies, as well as for controlling and measuring the direction and the motion of acoustic particles (Bhandiwad et al. 2013; Burgess \& Granato 2007). Importantly, the experiments need to be performed in sound-attenuated chambers (Bhandiwad et al. 2018, 2013; Burgess \& Granato 2007) to prevent interference of external noise and vibrations. While these studies often provided us with reliable and crucial insights on the sensorimotor function deficits endowed by the disease, the startle apparatus is rather costly and complicated, and considerable knowledge is required for setting up and performing the experiments.

Mechanical or tap stimulus presents as a simpler and more economical modality for studying startle response in zebrafish. In earlier studies, mechanical startle was generated by using a rubber hammer or by releasing a masking tape to a flat surface (Chanin et al. 2012). These methods were shown to produce adequate stimulus to evoke startle response in zebrafish. Automated method based on solenoid was later developed to improve the consistency and reproducibility of the tap stimuli (Eddins et al. 2010; Glazer et al. 2018; Rice et al. 2011). However, this startle modality is less popularly in use in zebrafish to study impairment in habituation response associated to human diseases, but more so for the studies of neurobehavioral effects due to environmental toxicants (Eddins et al. 2010; Glazer et al. 2018; Rice et al. 2011).

Zebrafish has been demonstrated to produce startle response as early as 5 days post fertilization (dpf), and habituation at $6 \mathrm{dpf}$ (Basnet et al. 2019). Although the blood-brain barrier in zebrafish larvae is fully developed only by $10 \mathrm{dpf}$ (Fleming et al. 2013), their midbrain barrier becomes sealed at $5 \mathrm{dpf}$ (O'Brown et al. 2019). In the current work, we evaluate whether tap stimuli can induce habituation response in the MK801-induced schizophrenia model of zebrafish at $6 \mathrm{dpf}$ using our custom-built startle apparatus.

\section{MATERIALS AND METHODS}

\section{ANIMALS}

Embryos were obtained from natural spawning of $\mathrm{AB}$ wild- type zebrafish (Danio rerio). They were reared in 96well microtiter plates in embryo (E3) medium $(5 \mathrm{mM} \mathrm{NaCl}$, $0.17 \mathrm{mM} \mathrm{KCl}, 0.33 \mathrm{mM} \mathrm{CaCl}$, and $0.33 \mathrm{mM} \mathrm{MgSO}, \mathrm{pH}$ 7.4) upon collection. Unfertilized and dead embryos were removed on the next day. The remaining embryos were maintained at $28{ }^{\circ} \mathrm{C}$ on a $14: 10$ light: dark cycle. To prevent the medium in the wells from drying out, the E3 medium was replenished daily until the days of experiments. All procedures performed in this study were approved by UTAR Scientific and Ethical Review Committee.

\section{DRUG TREATMENT}

Dizocilpine hydrogen maleate (MK801), a noncompetitive NMDA receptor antagonist was purchased from SigmaAldrich (St. Louis, USA). MK801 was dissolved in DMSO and diluted in E3 medium to a final concentration of $0.1 \%$ DMSO. On 6 dpf, a group of larval zebrafish $(\mathrm{n}=18)$ was treated with $20 \mu \mathrm{M}$ of MK801 for $3 \mathrm{~h}$ to model the symptoms of schizophrenia (Chen et al. 2010). Larvae in the control group $(n=18)$ was applied with $0.1 \%$ DMSO for $3 \mathrm{~h}$.

\section{STARTLE APPARATUS}

The startle apparatus consists of a single swim arena that is $30 \mathrm{~mm}$ in diameter and $10 \mathrm{~mm}$ in height. A $9 \mathrm{~V}$ push and pull solenoid is attached to the side of the arena to provide sudden taps. The two are mounted on a solid platform that holds them in place. The solenoid is toggled on and off by an Arduino Uno microcontroller that is programmed to control the timing of the taps. A recording camera at 30 frames per second was centrally positioned above the arena, $8 \mathrm{~cm}$ above the water level. A backlight illuminator is attached underneath the stage to provide additional lighting along with the fluorescent ceiling lights for video recording. The setup and the circuit diagram for the startle apparatus are illustrated in Figures 1 and 2 , respectively.

\section{STARTLE HABITUATION ASSAY}

Larvae were transferred to the swim arena of the startle apparatus that was filled with $3 \mathrm{~mL}$ of E3 medium following drug treatment. They were allowed to acclimate in the arena for at least $30 \mathrm{~min}$ prior to the test. Each 

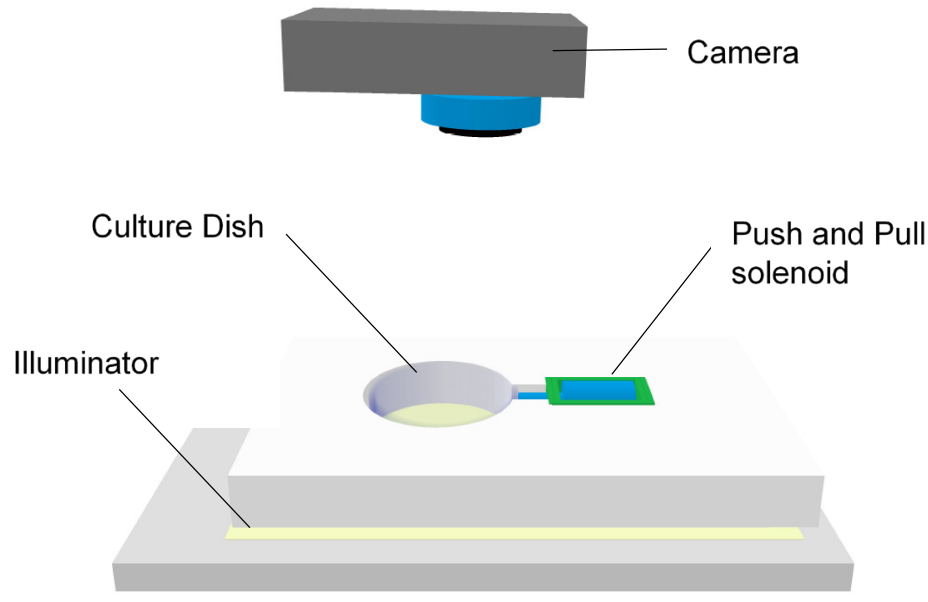

FIGURE 1. Setup for startle habituation assay. The startle apparatus consists of a single swim arena with a solenoid attached at the side

to produce sudden taps

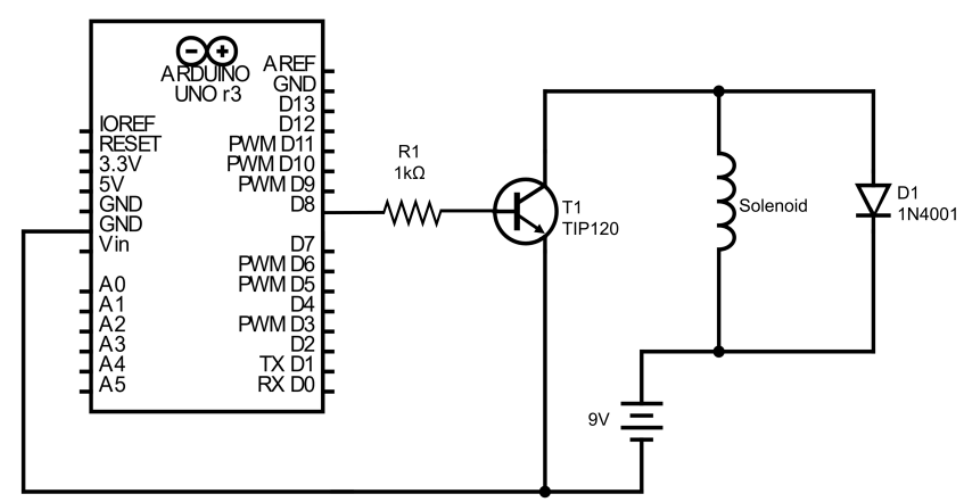

FIGURE 2. Circuit diagram of startle apparatus. The solenoid is driven by an Arduino Uno microcontroller to produce tap stimuli at the preset intervals

larva was subjected to 36 consecutive taps at the preset intervals. Videos were captured and processed offline using ToxTrac (Rodriguez et al. 2018) for fish tracking and activity analysis. All studies were performed between 11 am and $4 \mathrm{pm}$ as the activity of zebrafish larvae was found to be most stable within these hours (MacPhail et al. 2009).

\section{STATISTICAL ANALYSIS}

The statistical analysis was performed using Prism (Graphpad software Inc., San diego, CA). Welch's t-test was used to compare the difference in the area under the curve (AUC) between the control and the MK801treated larvae. Statistical power analysis was performed 
using G*Power (version 3.1.9.4; Dusseldorf University, Dusseldorf, Germany) to evaluate the performance of the current experiment.

\section{RESULTS}

Tap stimuli induced startle response in zebrafish, measured as the increase in distance moved across the swim arena compared to baseline, in both control and MK801-treated groups (Figure 3(A)). However, unlike the control, the response of the MK801-treated larvae did not habituate over startle trials. To quantify the overall startle response, the AUC was calculated (Best et al. 2008). The AUC of the MK801-treated larvae was significantly higher compared to the control (Figure 3(B), Welch's t-test, $p<0.0001$ ), confirming an impairment in the habituation response. Statistical power analysis showed that the study has a power of $99.92 \%$, indicating that our sample size assured an adequate power to detect at least $24 \%$ difference in the startle response of the two groups (assuming a type I error of 0.05).

Apart from the difference in the travelling distance, larvae from the two groups also demonstrated different swimming trajectory. Larvae from the control group exhibited a relatively ordered swimming pattern (Figure 3(C)) while larvae from the MK801-treated group swam chaotically through the arena without any deterministic
A

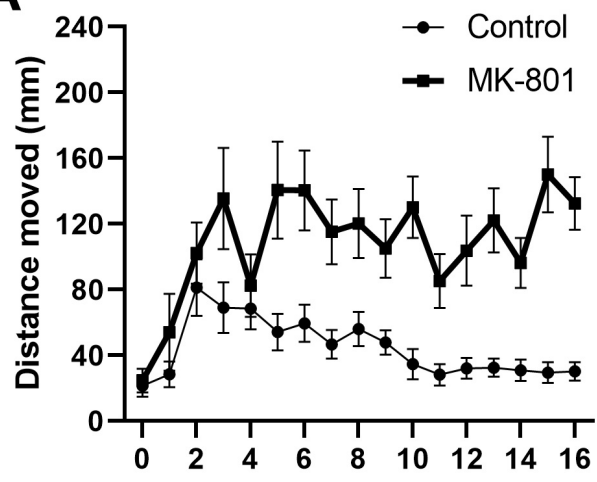

Startle Trials

C

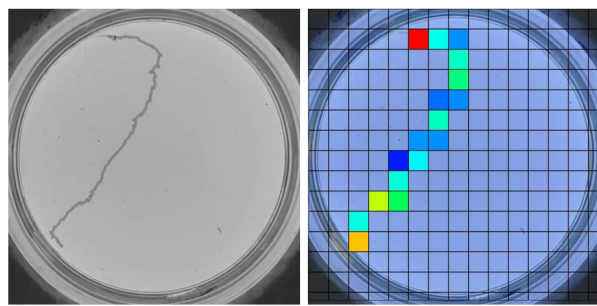

B

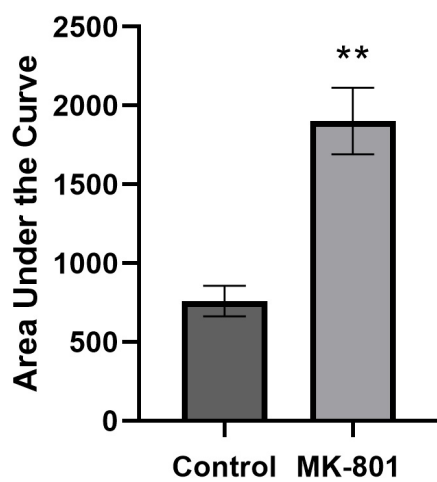

D

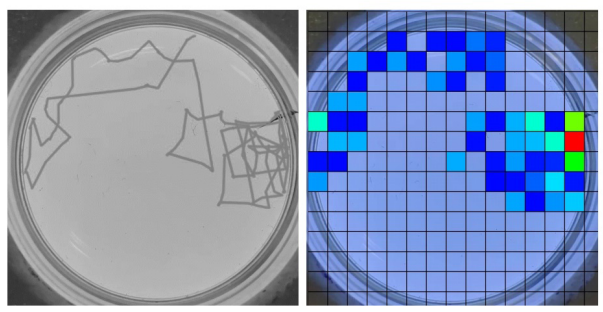

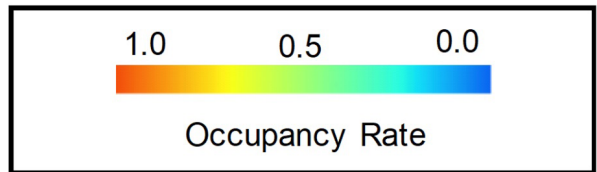

FIGURE 3. MK801 impaired habituation response in larval zebrafish. (A) Distance moved against startle trials for larvae from control and MK801-treated groups. For visual clarity purpose only the first 16 trials were shown. (B) Comparison of AUC of the two treatment groups. Data shown in $(A)$ and $(B)$ are mean \pm SEM $(n=18$ /data point) (C and D) Representative activity trajectory and occupancy plots for control (C) and MK801-treated (D) larvae, respectively. Color bar indicates how frequent a larva occupied a particular zone in the arena 
patterns (Figure 3(D)). Note that larvae from the control group spent a longer time at the center of arena, while those from the MK801-treated group tend to linger more frequently near the periphery of the arena.

\section{DISCUSSION}

This study provides a brief and simple technique for assessing the startle and habituation responses in larval zebrafish. As of acoustic startle, the tap stimuli produced using our custom apparatus adequately evoked startle response in larval zebrafish that habituated after the first few taps. Previous studies based on acoustic startle have shown that the rate of habituation varied with inter-trial intervals (ITIs), with a more rapid habituation response seen at a shorter ITI (Best et al. 2008; Thompson \& Spencer 1966). We similarly observed the same with mechanical startle and found that larval zebrafish habituated the greatest and fastest when subjected to tap stimuli at $1 \mathrm{~Hz}$ (data not shown).

There is strong evidence for deficient habituation among a substantial portion of schizophrenia patients (Bolino et al. 1994, 1992; Parwani et al. 2000). A significant impairment of habituation response was likewise observed in our pharmacological model of schizophrenia induced using MK801. Additional analysis of the swimming trajectories showed that the larvae treated with MK801 displayed a rather chaotic swimming pattern compared to the control in response to tap stimuli, mimicking the disordered or ataxia movements seen in schizophrenia rat models (Marcotte et al. 2001) and patients (Picard et al. 2008). Despite of the randomized swimming pattern, larvae administered with MK801 was found to spend a longer time at the periphery of the swim arena, reflecting a state of anxiety. Remarkably, the startle and habituation responses exhibited by MK801-treated larvae were also comparable to that elicited by acoustic startle in the zebrafish model of schizophrenia induced using donepezil (Best et al. 2008), suggesting tap stimuli to be an effective modality for assessing information processing deficits in schizophrenia.

Like most of the automated commercial and custom mechanical startle apparatus (Eddins et al. 2010; Glazer et al. 2018), DC solenoid is used as the actuator for producing sudden taps in our study. However, instead of controlling the timing of the solenoid using software running on the computer, the timing of the stimuli was pre-programmed in the microcontroller to increase the portability. For high throughput analysis, the system can be modified by increasing the number of solenoids and by adding relays at the output pins of the microcontroller to control the individual solenoids. Importantly, since the design uses only off-the-shelf components, it can be readily and be inexpensively reproduced in other laboratories.

\section{CONCLUSION}

Overall, our results suggest that mechanical startle is an appropriate and reliable alternative for studying habituation response in the schizophrenia model of zebrafish. Although the present technique was tested only in the schizophrenia model induced using MK801, it may be extended for the studies of other pharmacological models in zebrafish that associated with impaired habituation response.

\section{ACKNOWLEDGEMENTS}

This work was supported by UTARRF grants IPSR/ RMC/UTARRF/2018-C1/M05 and IPSR/RMC/ UTARRF/2019-C1/M01, by MTSF grant 4417/M01, and by FGRS grant FRGS/1/2018/STG03/UTAR/02/1.

\section{REFERENCES}

Abel, K., Waikar, M., Pedro, B., Hemsley, D. \& Geyer, M. 1998. Repeated testing of prepulse inhibition and habituation of the startle reflex: A study in healthy human controls. Journal of Psychopharmacology 12(4): 330-337.

Basnet, R.M., Zizioli, D., Taweedet, S., Finazzi, D. \& Memo, M. 2019. Zebrafish larvae as a behavioral model in neuropharmacology. Biomedicines 7(1): 23.

Best, J.D., Berghmans, S., Hunt, J.J.F.G., Clarke, S.C., Fleming, A., Goldsmith, P. \& Roach, A.G. 2008. Non-associative learning in larval zebrafish. Neuropsychopharmacology 33(5): 1206-1215.

Bhandiwad, A.A., Raible, D.W., Rubel, E.W. \& Sisneros, J.A. 2018. Noise-induced hypersensitization of the acoustic startle response in larval zebrafish. Journal of the Association for Research in Otolaryngology 19(6): 741-752.

Bhandiwad, A.A., Zeddies, D.G., Raible, D.W., Rubel, E.W. \& Sisneros, J.A. 2013. Auditory sensitivity of larval zebrafish (Danio rerio) measured using a behavioral prepulse inhibition assay. Journal of Experimental Biology 216(18): 3504-3513.

Bolino, F., Di Michele, V., Di Cicco, L., Manna, V., Daneluzzo, E. \& Casacchia, M. 1994. Sensorimotor gating and habituation evoked by electro-cutaneous stimulation in schizophrenia. Biological Psychiatry 36(10): 670-679.

Bolino, F., Manna, V., Di Cicco, L., Di Michele, V., Daneluzzo, E., Rossi, A. \& Casacchia, M. 1992. Startle reflex habituation in functional psychoses: A controlled study. Neuroscience Letters 145(2): 126-128.

Burgess, H.A. \& Granato, M. 2007. Sensorimotor gating in larval zebrafish. Journal of Neuroscience 27(18): 4984-4994.

Chanin, S., Fryar, C., Varga, D., Raymond, J., Kyzar, E., Enriquez, J., Bagawandoss, S., Gaikwad, S., Roth, A., Pham, M., Zapolsky, I., Bruce, I., Hester, J., Green, J., Desmond, D., Stewart, A.M. \& Kalueff, A.V. 2012. Assessing startle responses and their habituation in adult zebrafish. In Zebrafish Protocols for Neurobehavioral Research, edited by Kalueff, A.V. \& Stewart, A.M. Humana Press: Springer Science+Business Media. pp. 287-300.

Chen, J., Patel, R., Friedman, T.C. \& Jones, K.S. 2010. The behavioral and pharmacological actions of NMDA 
receptor antagonism are conserved in zebrafish larvae. International Journal of Comparative Psychology 23(1): 82-90.

Eddins, D., Cerutti, D., Williams, P., Linney, E. \& Levin, E.D. 2010. Zebrafish provide a sensitive model of persisting neurobehavioral effects of developmental chlorpyrifos exposure: Comparison with nicotine and pilocarpine effects and relationship to dopamine deficits. Neurotoxicology and Teratology 32(1): 99-108.

Fleming, A., Diekmann, H. \& Goldsmith, P. 2013. Functional characterisation of the maturation of the blood-brain barrier in larval zebrafish. PLOS ONE 8(10): e77548.

Gawel, K., Banono, N.S., Michalak, A. \& Esguerra, C.V. 2019. A critical review of zebrafish schizophrenia models: Time for validation? Neuroscience and Biobehavioral Reviews 107: 6-22.

Geyer, M.A. \& Braff, D.L. 1982. Habituation of the blink reflex in normals and schizophrenic patients. Psychophysiology 19(1): $1-6$

Geyer, M.A., Swerdlow, N.R., Mansbach, R.S. \& Braff, D.L. 1990. Startle response models of sensorimotor gating and habituation deficits in schizophrenia. Brain Research Bulletin 25(3): 485-498.

Glazer, L., Wells, C.N., Drastal, M., Odamah, K.A., Galat, R.E., Behl, M. \& Levin, E.D. 2018. Developmental exposure to low concentrations of two brominated flame retardants, BDE-47 and BDE-99, causes life-long behavioral alterations in zebrafish. NeuroToxicology 66: 221-232.

MacPhail, R.C., Brooks, J., Hunter, D.L., Padnos, B., Irons, T.D. \& Padilla, S. 2009. Locomotion in larval zebrafish: Influence of time of day, lighting and ethanol. NeuroToxicology 30(1): 52-58.

Marcotte, E.R., Pearson, D.M. \& Srivastava, L.K. 2001. Animal models of schizophrenia: A critical review. Journal of Psychiatry and Neuroscience 26(5): 395-410.

Norton, W.H.J. 2013. Towards developmental models of psychiatric disorders in zebrafish. Frontiers in Neural Circuits 7: 79.

O’Brown, N.M., Megason, S.G. \& Gu, C. 2019. Suppression of transcytosis regulates zebrafish blood-brain barrier function. ELife 8: e47326.

Parwani, A., Duncan, E.J., Bartlett, E., Madonick, S.H., Efferen, T.R., Rajan, R., Sanfilipo, M., Chappell, P.B., Chakravorty, S., Gonzenbach, S., Ko, G.N. \& Rotrosen, J.P. 2000. Impaired prepulse inhibition of acoustic startle in schizophrenia. Biological Psychiatry 47(7): 662-669.
Picard, H., Amado, I., Mouchet-Mages, S., Olié, J.P. \& Krebs, M.O. 2008. The role of the cerebellum in schizophrenia: An update of clinical, cognitive, and functional evidences. Schizophrenia Bulletin 34(1): 155-172.

Rice, C., Ghorai, J.K., Zalewski, K. \& Weber, D.N. 2011. Developmental lead exposure causes startle response deficits in zebrafish. Aquatic Toxicology 105(3-4): 600-608.

Rodriguez, A., Zhang, H., Klaminder, J., Brodin, T., Andersson, P.L. \& Andersson, M. 2018. ToxTrac: A fast and robust software for tracking organisms. Methods in Ecology and Evolution 9(3): 460-464.

Swerdlow, N.R., Caine, S.B., Braff, D.L. \& Geyer, M.A. 1992. The neural substrates of sensorimotor gating of the startle reflex: A review of recent findings and their implications. Journal of Psychopharmacology 6(2): 176-190.

Thompson, R.F. \& Spencer, W.A. 1966. Habituation: A model phenomenon for the study of neuronal substrates of behavior. Psychological Review 73(1): 16-43.

Wang, X., Ding, S., Lu, Y., Jiao, Z., Zhang, L., Zhang, Y., Yang, Y., Zhang, Y., Li, W. \& Lv, L. 2019. Effects of sodium nitroprusside in the acute dizocilpine (MK-801) animal model of schizophrenia. Brain Research Bulletin 147: 140-147.

Wood, J.D., Bonath, F., Kumar, S., Ross, C.A. \& Cunliffe, V.T. 2009. Disrupted-in-schizophrenia 1 and neuregulin 1 are required for the specification of oligodendrocytes and neurones in the zebrafish brain. Human Molecular Genetics 18(3): 391-404

Wen-Yang Png, Pek-Yee Tang \& Siew-Ying Mok* Department of Mechatronics and Biomedical Engineering Universiti Tunku Abdul Rahman Jalan Sungai Long, Bandar Sungai Long Cheras, 43000 Kajang, Selangor Darul Ehsan Malaysia

Satoshi Ogawa \& Ishwar Parhar

Brain Research Institute

Jeffrey Cheah School of Medicine and Health Sciences

Monash University Malaysia

47500 Bandar Sunway, Selangor Darul Ehsan

Malaysia

*Corresponding author; email: moksy@utar.edu.my

Received: 10 April 2020

Accepted: 19 June 2020 